\title{
A focus on inspiring Biblical spirituality
}

\begin{abstract}
Book Title:
The Spirit That Inspires:

Perspectives on Biblical

Spirituality (Acta Theologica

Suppl. 15)
\end{abstract}

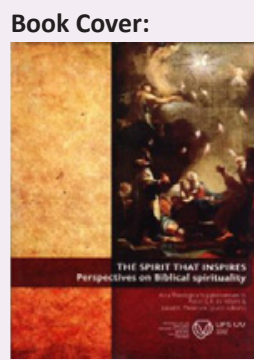

Editors:

De Villiers, P.G.R. \& Lloyd, K.P.

ISBN:

1015-8758.

Publisher:

SUN MeDIA Bloemfontein,

2011, R120*

*Book price at time of review

\section{(1}

Review Title:

A focus on inspiring Biblical spirituality

Reviewer:

Dirk G. van der Merwe ${ }^{1}$

\section{Affiliation:}

${ }^{1}$ Department of Christian

Spirituality, Church History

and Missiology, University of

South Africa, South Africa

Email:

dirkvdm7@gmail.com

Postal address:

University of South Africa,

PO Box 392, Unisa 0003

South Africa

How to cite this book review: Van der Merwe, D.G., 2012, 'A focus on inspiring Biblical spirituality', In die Skriflig/ In Luce Verbi 46(1), Art. \#132, 3 pages. $\mathrm{http} / / \mathrm{dx}$.doi. org/10.4102/ids.v46i1.132

C 2012. The Authors Licensee: AOSIS OpenJournals. This work is licensed under the Creative Commons Attribution License.
The Spirit that Inspires: Perspectives on Biblical Spirituality is a compendium of papers presented at a symposium on the Bible and Spirituality, held at Glenfall House, Cheltenham from 04 to 06 May and hosted by the University of Gloucestershire. The aim of this symposium was to reflect upon the discipline of Biblical Spirituality. Eleven papers were read and discussed at this symposium by well-known scholars in the discipline of Spirituality, coming from the Netherlands, South Africa and the United Kingdom.

The first essay comes from the world renowned scholar in the discipline of Spirituality, Kees Waaijman, with his contribution of Biblical Spirituality: An 'other' reading. He discusses the communicative dimension and dialogical dynamic of a text. His purpose was to shed some light on the relationship between Biblical Spirituality and the Bible. His research illustrates two strategies of reading the Bible: the action of the author-text on the reader and the action of the reader in relation to the text. These two strategies he illustrates in terms of seven paradigms. This, according to him, points out how the essence of pragmatics lies in the fact that the polar tension does not allow for indifference on the part of the reader. He is convinced that the transition from an awareness of differences in respect of content to dialogical non-indifference is crucial for Biblical Spirituality' (p. 1). Such a transition marks the progression from a meditative way of reading, which is directed towards content, to an orative [prayerful] way of reading, which is concerned with the God-human process of transformation. Waaijman's contribution is to create the awareness of the negotiation between the reader and the text, via the dialogical dynamic, for a lived experience.

The next two essays come from Huub Welzen. His first essay is an Exegetical analyses and spiritual readings of the story of the annunciation (Lk 1:26-38). In this essay, Welzen presents four readings of Luke 1:26-38 together with evaluations regarding their possibilities for spirituality. The first reading is a form of critical analysis. He uses the work of Lohfink in whose approach is focused on Jesus. The other characters, namely God, Gabriel and Mary, hardly receive any attention. In the second reading, his analysis views Mary as a prototype of liberation spirituality. This reading is informed by semiotic analysis and the sociology of literature. His third reading is based on narrative criticism. Here he focuses on what happens to the characters of the story. The fourth reading is an intertextual one. It shows how the quotation of Genesis 18:14 becomes an expression of one of the specific topics relating to the spirituality of Luke's Gospel. Welzen's conclusion is that no specific method is decisive for spirituality. Crucial is the openness of the researcher. This spells out how important the role of the interpreter is as well as the need to account for his orher interpretation in an adequate and critical scientific manner.

In his second essay, Welzen focuses on the contours of biblical spirituality as a discipline. He uses three approaches to define biblical spirituality. The first approach is from lived spirituality. In the bipolarity of the text and reader, it is the reader who attributes meaning to the text guided by the data of the text. His second approach focusses on the fact that there are many different spiritualties both in the Bible and in its readers. These spiritualities are influenced by their contexts. The third approach discusses the composing terms. His definition is that biblical spirituality is about the divine human relational process in the Bible and about the Bible in the divine human relational process. For Welzen, doing research, a threefold competence is needed: in exegesis, in spirituality and in the integration of these two. This research shows the dynamic nature of spirituality.

In his essay, Spirituality in a secular age: From Charles Taylor to study of the Bible and spirituality, Lincoln proposes that those engaged in studying the Bible with regard to spirituality would benefit from being aware of Charles Taylor's thinking in A Secular Age. Although this book is a narrative about the emergence of the secular Western civilization, it also concerns the role of the spiritual in this civilization. The essay indicates the significance of Taylor's work for understanding the 
present context of the experience of spirituality. This work reflects on the potential of the work of Taylor 'for those who are interested in dialogue between a spirituality rooted in biblical perspectives and contemporary forms of spirituality, focussing on his notion of "fullness"" (p. 61). Lincoln shows how scholars (like Taylor) offer insights and helpful ideas that would appeal to anyone who studies biblical spirituality today.

The essay of Gordon McConville, Happiness in the Psalms, enquires into the nature of happiness or well-being in the Old Testament Psalms. It considers first the use of happiness language in the psalms, and then continues to seek a broader basis for the enquiry in key concepts such as freedom and justice making some comparisons with Greek ideas. It also seeks to build up a picture of the person at the centre of the psalms and then as the one who speaks. With this he shows the practical and relevancy of ancient texts in the psalms for contemporary spiritual life.

Pieter De Villiers discusses in his essay some apocalyptic perspectives on Luke's portrayal of 'The resurrection as Christ's entry into his glory (Lk 24:26). His objective was to point out the mystical nature of the resurrection. His research started with a discussion of recent developments in research on Luke's Christology and apocalyptic literature. This is followed by a discussion of the importance of glory in Early Jewish and Christian apocalypses. De Villiers explains the glory motif in Luke 24:26, its place in the resurrection account in Luke in general and in the Emmaus story in particular. He draws a comparison between the mystical uses of the glory motif in Luke 24:26 and Luke's use of glory elsewhere in his writings. He points out apocalyptic perspectives in Luke's description of Jesus's resurrection and their mystical implications. For Luke, the resurrection of Jesus was an entry into glory. This is a mystical motif in Hebrew Scriptures as well as in Jewish and Christian apocalyptic texts. For De Villiers, the category of mysticism, which is central to spirituality, should be approached from a contextual perspective. Such an approach should take into account that language and concepts of mysticism in antiquity articulated the conviction that there is an intimate, close relationship between God and humanity. According to him, it is important to understand that this relationship is portrayed in terminology characteristic of its own time. Therefore, the anachronistic reading of texts from modern mystical perceptions in biblical spirituality is not acceptable.

In her essay Reading Scripture through a mystical lens Celia Kourie pays attention to a mystical approach to biblical texts. Her point of departure is the contemporary insights of Catez to read Paul through a mystical lens. For her, these insights go back as far as those of Origin. Her contribution complements the works of Welzen and Waaijman. She also emphasizes that the text can no longer be read simply as a historical artefact. She extends the remarks of Welzen about the significant role of the researcher in spiritual readings of the Bible. This is verified by her analysis of the experiences of those who read the Bible. The experiences of readers show the polysemous nature of the Bible. The importance of a spiritual reading of scripture has now come to the fore.

Lloyd Pietersen also works with a particular text in order to determine its relevance to understand biblical spirituality. He draws on the understanding of the social imaginary of Taylor and the understanding of spirituality of Waaijman and examines the contention on the prevalence of good citizenship in the Pastoral letters by Dibelius. For this he examines the concept of eusebeia (godliness and/or piety) in the light of the lived experience of pagans, Jews and Christians in the first-century Ephesus. Working specifically with Ephesus, Pietersen takes seriously the context in which Biblical texts should be understood. This again emphasizes the importance and relevance of the ancient socio-historical environment for Biblical Spirituality.

Francois Tolmie also pays attention to a particular text to investigate the spirituality of that text. As a specialist on Galatians, he examines this epistle as a whole in terms of Waaijman's hermeneutical model. He does this from the perspective of spirituality. He concentrated on the divinehuman relationship and to the notion of transformation. With this approach of textual analysis, Tolmie exemplifies the need for basic and thorough readings of biblical texts with regard to discover the spirituality embedded in the biblical text.

Paul de Kock discusses the transformative potential of the Apocalypse of John through the divine wisdom it offers by way of various symbols. These symbols help the readers to perceive themselves and their world in new ways. This would enable them to discern between the divine and evil ways. This transformation is not merely an individual and temporary one but is cosmic, social and divine-human. This strengthens and empowers the readers to persevere in doing the works of Jesus and holding on to their witness of Jesus.

The last essay comes from Jos Huls. His approach is somewhat different from the rest in this publication. In his essay, Conrad's allegorical reading of 1 Samuel 14: an analysis of a sermon by Conrad of Saint George on the worthy reception of the Blessed Sacrament, he investigates the use of the Bible in later spirituality. In this effort, he analyses a sermon of Saint George on the reception of the Sacrament as a paradigm for the allegorical genre of reading in the Middle Ages. For him, this mode of reading relates the Bible text to our lives. This then places the relationship with God in a central position. The text is an expression of a divine address. Subsequently, the whole of the text is read from the perspective of the mystagogic moment as the reader's personal transformation process. Huls is of opinion that in such a way the historical 
context is terminated and the development of the spiritual path becomes central. This shows that the allegorical mode of reading has its own logic and cannot merely be dismissed as human fantasy. Huls's essay illustrates how the reading and interpretation of the Bible is enriched by drawing on later interpretations.

In this publication, three major areas of research within biblical spirituality have been explored: spirituality in the Bible, the Bible in spirituality and spiritual hermeneutics (p. iv). Although the discipline of spirituality is very young as an academic discipline in comparison with other theological disciplines, it is just remarkable how much this discipline has developed over the past two decades. This is evident from these essays. Many publications on spirituality and also biblical spirituality are of highly academic standard. This publication of The Spirit that Inspires: Perspectives on Biblical Spirituality is also an excellent piece of scholarship. For those really interested in spirituality is this edition absolutely stimulating and refreshing. It certainly makes a good academic contribution to the discipline of Christian spirituality, especially biblical spirituality. The reading of these essays not only enriches this discipline but also stimulates the desire with the reader for further related research. 